\title{
Development of an Operational Space Using Mechanistic Models for a Pd- Catalyzed Amidation Reaction Used in the Synthesis of ABT-530
}

\author{
Daniel D. Caspi, Moiz Diwan, Jean-Christophe C. Califano, Daniel J. Mack, and Shashank Shekhar* \\ Process Research and Development, AbbVie Inc., 1 North Waukegan Road, North Chicago, Illinois \\ 60064, United States
}

*Corresponding author email: Shashank.shekhar@abbvie.com

\section{Supporting Information}

General methods. All palladium-catalyzed reactions were performed in a nitrogen-filled glove box. tert-Butyl (S)2-carbamoylpyrrolidine-1-carboxylate, $\mathrm{Pd}(\mathrm{OAc})_{2}$, XantPhos, $\mathrm{K}_{2} \mathrm{CO}_{3}$, and isopropyl acetate were purchased from commercial sources and were used without further purification, unless noted specifically. ${ }^{1} \mathrm{H}$ and ${ }^{13} \mathrm{C}$ NMR spectra were recorded on a 400, 500, 600 or $700 \mathrm{MHz}$ spectrometer, with shifts reported in parts per million downfield from tetramethylsilane and referenced to residual proton $\left({ }^{1} \mathrm{H}\right)$ or deuterated solvent $\left({ }^{13} \mathrm{C}\right)$. HPLC analyses were performed using spectroscopic grades of acetonitrile and water with $0.2 \% \mathrm{HClO}_{4}$ as eluents.

Experimental procedure for Pd-catalyzed amidation (Step 1, Figure 1): Inside an inert atmosphere glove box, $\mathrm{Pd}(\mathrm{OAc})_{2}$ (2.9 mg, $\left.0.013 \mathrm{mmol}\right)$, XantPhos (11 mg, $\left.0.019 \mathrm{mmol}\right), \mathrm{K}_{2} \mathrm{CO}_{3}(0.59 \mathrm{~g}, 4.2 \mathrm{mmol})$, tert-butyl 2carbamoylpyrrolidine-1-carboxylate (Boc-ProNH2) (0.91 g, $4.2 \mathrm{mmol})$, and 1-(4-((2R,5R)-2,5-bis(4-chloro-2fluoro-5-nitrophenyl)pyrrolidin-1-yl)-2,6-difluorophenyl)-4-(4-fluorophenyl)piperidine (1) (1.0 g, 1.4 mmol) were charged to a $40-\mathrm{mL}$ vial equipped with a magnetic stir bar. Isopropyl acetate (IPAc) was sparged with nitrogen and was brought inside the glove box. IPAc $(10 \mathrm{~mL})$ was added to the above solution and stirred. The vial was capped, the reaction mixture was heated to $88^{\circ} \mathrm{C}$ and stirred for 8-12 h. Upon reaction completion, the mixture was cooled down to the room temperature and was brought outside of the glove box. Water $(10 \mathrm{~g})$ containing $\mathrm{Na}_{2} \mathrm{CO}_{3}(0.5 \mathrm{~g})$ and L-cysteine $(0.5 \mathrm{~g})$ was added to the flask and the solution was mixed to obtain clear, biphasic solution, which was transferred to a separatory funnel. The aqueous layer was removed and the organic layer was washed again with water $(10 \mathrm{~g})$ containing $\mathrm{Na}_{2} \mathrm{CO}_{3}(0.5 \mathrm{~g})$ and L-cysteine $(0.5 \mathrm{~g})$. The organic layer was washed sequentially with water $(10 \mathrm{~g})$ containing $\mathrm{Na}_{2} \mathrm{CO}_{3}(0.5 \mathrm{~g})$ and water $(10 \mathrm{~g})$ containing $\mathrm{NaCl}(1 \mathrm{~g})$. The organic layer was filtered through a pad of carbon, washed with IPAc $(5 \mathrm{~mL})$ and concentrated in vacuo to $\sim 4 \mathrm{~mL}$. Methanol $(11 \mathrm{~mL})$ was added to the concentrated IPAc solution over $3 \mathrm{~h}$ with stirring at the room temperature. A white slurry was observed that was mixed for $30 \mathrm{~min}$ at the room temperature then heated to $55^{\circ} \mathrm{C}$, stirred for $2 \mathrm{~h}$ at $55^{\circ} \mathrm{C}$ and then cooled down to $25^{\circ} \mathrm{C}$. The amidation product (3) was collected by filtration, washed with $\mathrm{MeOH}(5 \mathrm{ml})$ then dried in a vacuum oven for $12 \mathrm{~h}$ at $50{ }^{\circ} \mathrm{C}$. The coupled product was isolated in $80-85 \%$ yield $(1.2-1.3 \mathrm{~g})$ by following this procedure. ${ }^{1} \mathrm{H}$ NMR $(700 \mathrm{MHz}$, Chloroform- $d$ ) $\delta 11.18(\mathrm{~s}, 2 \mathrm{H}), 8.77(\mathrm{~d}, J=12.9 \mathrm{~Hz}, 2 \mathrm{H}), 7.82(\mathrm{~d}, J=7.2 \mathrm{~Hz}, 2 \mathrm{H})$, $7.18(\mathrm{dd}, J=8.4,5.5 \mathrm{~Hz}, 2 \mathrm{H}), 6.96(\mathrm{t}, J=8.6 \mathrm{~Hz}, 2 \mathrm{H}), 5.82(\mathrm{~d}, J=12.4 \mathrm{~Hz}, 2 \mathrm{H}), 5.39(\mathrm{~d}, J=6.2 \mathrm{~Hz}, 2 \mathrm{H}), 4.42(\mathrm{~d}, J$ $=83.0 \mathrm{~Hz}, 2 \mathrm{H}), 3.74-3.33(\mathrm{~m}, 4 \mathrm{H}), 3.20-3.02(\mathrm{~m}, 4 \mathrm{H}), 2.55(\mathrm{tq}, J=9.5,5.5,4.9 \mathrm{~Hz}, 2 \mathrm{H}), 2.18(\mathrm{~d}, J=52.9 \mathrm{~Hz}$, $4 \mathrm{H}), 1.94$ (ddt, $J=27.8,22.5,10.7 \mathrm{~Hz}, 6 \mathrm{H}), 1.86-1.71(\mathrm{~m}, 4 \mathrm{H}), 1.44(\mathrm{~d}, J=54.2 \mathrm{~Hz}, 18 \mathrm{H}) .{ }^{13} \mathrm{C}$ NMR $(176 \mathrm{MHz}$, $\left.\mathrm{CDCl}_{3}\right) \delta 172.55,164.76,163.30,162.10,161.11,161.05,160.72,159.71,159.65,155.49,142.40,140.33,136.18$, $132.76,128.35,128.30,125.45,124.98,119.42,115.22,115.10,109.70,109.54,98.05,97.89,96.26,81.20,62.33$, $56.77,52.69,47.49,41.78,34.51,34.45,31.03,30.28,28.47,24.67$.

Representative Experimental procedure to monitor the Step 1 reaction over time with HPLC: Inside an inert atmosphere glove box, $\mathrm{Pd}(\mathrm{OAc})_{2}(2.9 \mathrm{mg}, 0.013 \mathrm{mmol})$, XantPhos $(11 \mathrm{mg}, 0.019 \mathrm{mmol}), \mathrm{K}_{2} \mathrm{CO}_{3}(0.59 \mathrm{~g}, 4.2 \mathrm{mmol})$, tert-butyl 2-carbamoylpyrrolidine-1-carboxylate $\left(\mathrm{Boc}_{-} \mathrm{ProNH}_{2}\right)(0.91 \mathrm{~g}, 4.2 \mathrm{mmol}), 1-(4-((2 \mathrm{R}, 5 \mathrm{R})-2,5$-bis(4-chloro2-fluoro-5-nitrophenyl)pyrrolidin-1-yl)-2,6-difluorophenyl)-4-(4-fluorophenyl)piperidine (1) (1.0 g, $1.4 \mathrm{mmol}$ ), and 4,4'-dimethyl-1,1'-biphenyl (internal standard) $(0.13 \mathrm{~g}, 0.71 \mathrm{mmol})$ were charged to a $40-\mathrm{mL}$ vial equipped with a 
magnetic stir bar. Isopropyl acetate (IPAc) was sparged with nitrogen and was brought inside the glove box. IPAc $(10 \mathrm{~mL})$ was added to the above solution and stirred. The vial was capped, the reaction mixture was heated to $88^{\circ} \mathrm{C}$ and stirred. Samples $(10 \mu \mathrm{L})$ were withdrawn with a $50 \mu \mathrm{L}$ syringe over the course of the reaction, diluted with a mixture of MeCN $(1 \mathrm{~mL})$ and water $(0.1 \mathrm{~mL})$ and analyzed by HPLC.

\section{$\underline{\text { HPLC method }}$}

Column: Ascentis Express C18

Dimensions: 15 x $4.6 \mathrm{~mm}, 2.7$ micron

Temperature: $45^{\circ} \mathrm{C}$

Flow rate: $1.5 \mathrm{~mL} / \mathrm{min}$

Solvent A: Water $\left(0.2 \% \mathrm{HClO}_{4}\right)$

Solvent B: MeCN

Method: Time $=0(47 \% \mathrm{~A} / 53 \% \mathrm{~B})$, ramp to $(17 \% \mathrm{~A} / 73 \% \mathrm{~B})$ over $33 \mathrm{~min}$, ramp to $(5 \% \mathrm{~A} / 95 \% \mathrm{~B})$ over 6 min, hold for $(5 \% \mathrm{~A} / 95 \% \mathrm{~B})$ for $2 \mathrm{~min}$, ramp to $(47 \% \mathrm{~A} / 53 \% \mathrm{~B})$ over $0.1 \mathrm{~min}$ then hold for 3.9 min.

Retention times: Boc-ProNH 2 (0.96 min), 4,4'-Dimethyl-1,1'-biphenyl (11.1 min), 7 (23.8 min), 1 (24.9 min), ClArArNHPro (28.1 min), and 3 (30.6 min).

The concentration of 1, 3, 7, Boc-ProNH ${ }_{2}$, and ClArArNHPro were determined by HPLC as follows. An HPLC standard of the internal standard was prepared by weighing 4'4'-dimethyl-1,1'-biphenyl (12.4 mg) into a $50 \mathrm{~mL}$ volumetric flask and diluted to $50 \mathrm{~mL}$ with acetonitrile. A sample was injected into HPLC and area was recorded. Area $/(\mathrm{mg} / \mathrm{mL})$ (A_int_std) was calculated. HPLC standard of each 'product' $\left(\mathbf{1}, \mathbf{3}, \mathbf{7}\right.$, Boc-ProNH ${ }_{2}$, and ClArArNHPro) was prepared by weighing a known amount of the 'product' into a $50 \mathrm{~mL}$ volumetric flask and diluting it to $50 \mathrm{~mL}$ with acetonitrile. A sample was injected into HPLC and area was recorded. Area/(mg/mL) (A_pdt_std) was calculated. The following formula was used to calculate concentration of each 'product' during the reaction.

[Product] $(M)=\frac{A_{\text {prod }} \times W_{\text {std }}(g) \text { X A_int_std } \times 1000}{A_{\text {std }} \text { X A_pdt_std } X M . \text { Wt._pdt }(g / \mathrm{mol}) \times \text { reaction volume }(\mathrm{mL})}$ 


\section{Synthesis of 7.}
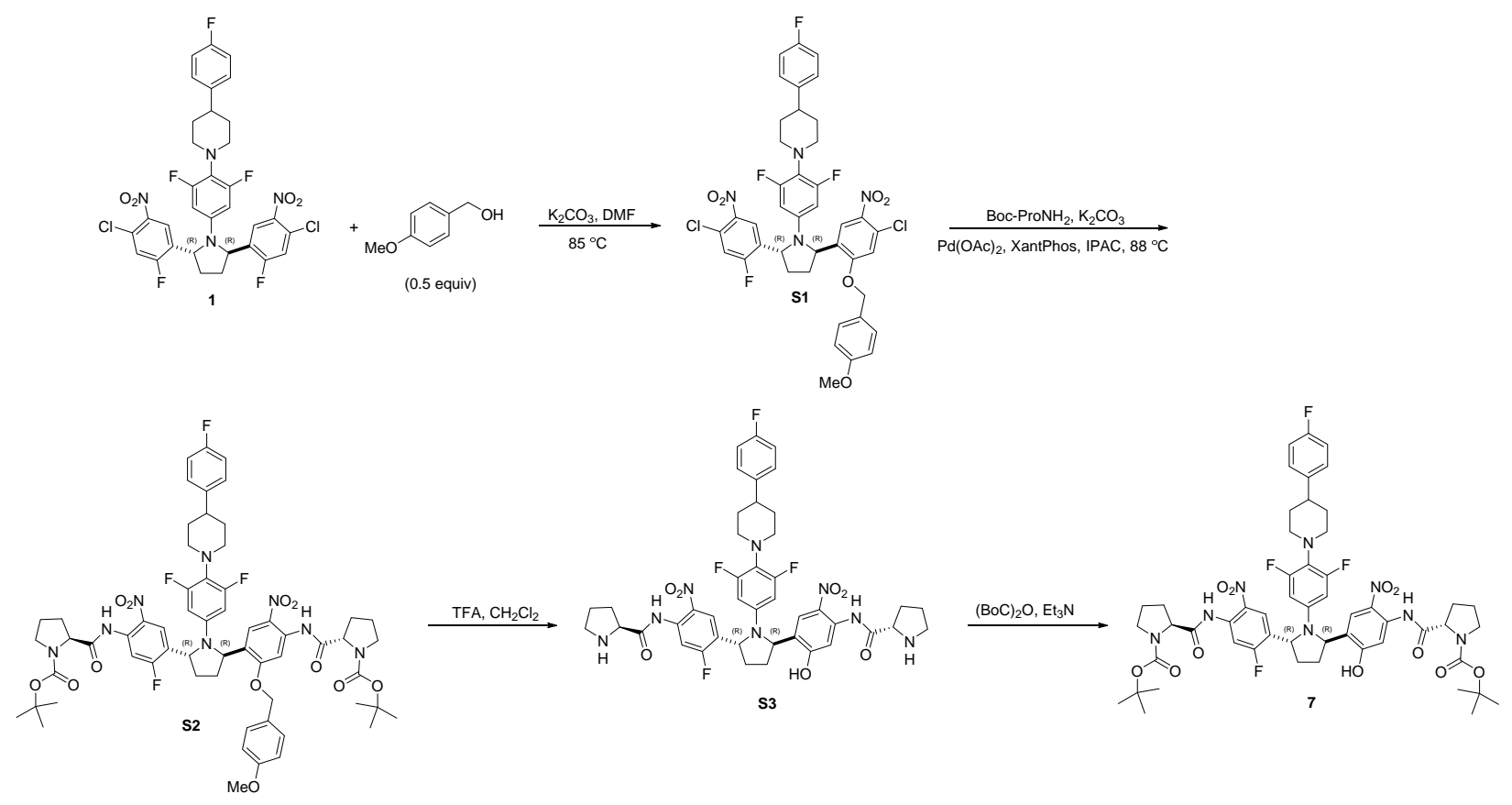

p-Methoxybenzyl alcohol (0.495 g, $3.58 \mathrm{mmol}), 1(5.0 \mathrm{~g}, 7.1 \mathrm{mmol}), \mathrm{K}_{2} \mathrm{CO}_{3}(1.0 \mathrm{~g}, 7.2 \mathrm{mmol})$, and dimethylformamide $(30 \mathrm{~mL})$ were charged to a $100 \mathrm{~mL}$ vial equipped with a magnetic stir bar. The reaction temperature was raised to $85^{\circ} \mathrm{C}$ and the contents were mixed overnight. The reaction was cooled down to the room temperature, diluted with ethyl acetate $(300 \mathrm{~mL})$ and washed with water $(3 \times 100 \mathrm{~mL})$. The organic layer was evaporated to obtain a viscous oil. The crude product was purified by column chromatography using EtOAc/heptanes $(0-10 \%)$ as eluent. The product containing fraction were combined and concentrated in vacuo to obtain S1 (1.28 g, 22\%) as yellow solid.

Inside an inert atmosphere glove box, $\mathrm{Pd}(\mathrm{OAc})_{2}(14 \mathrm{mg}, 0.061 \mathrm{mmol}, 5 \mathrm{~mol} \%)$, XantPhos (53 mg, $0.092 \mathrm{mmol}, 7.5$ mol\%), $\mathrm{K}_{2} \mathrm{CO}_{3}$ (510 mg, $3.69 \mathrm{mmol}, 3$ equiv), Boc-ProNH $\mathrm{H}_{2}(790 \mathrm{mg}, 3.69 \mathrm{mmol}, 3$ equiv), and $\mathbf{S 1}$ (1.0 g, $1.2 \mathrm{mmol}$, 1 equiv) were charged to a $40-\mathrm{mL}$ vial equipped with a magnetic stir bar. IPAc was sparged with nitrogen and was brought inside the glove box. IPAc $(25 \mathrm{~mL})$ was added to the above solution and stirred. The vial was capped, the reaction mixture was heated to $88^{\circ} \mathrm{C}$ and stirred for $16 \mathrm{~h}$. The reaction mixture was cooled to the room temperature, washed with $10 \mathrm{~mL}$ water followed by with $10 \mathrm{~mL}$ saturated $\mathrm{NaCl}$ then concentrated to dryness in vacuo to obtain an oil. The crude product was purified by column chromatography using EtOAc/heptanes (0-25\%) as eluent to obtain S2 as yellow solid (1.2 g, 27\%).

S2 $(1.05 \mathrm{~g}, 0.89 \mathrm{mmol})$ was charged to a $40-\mathrm{mL}$ vial equipped with a magnetic stir bar. Dichloromethane $(10 \mathrm{~mL})$ and trifluoroacetic acid $(10 \mathrm{~mL})$ were added and the solution was mixed overnight at the room temperature. The solvent was removed under vacuum and the residue was dissolved in IPAc $(15 \mathrm{~mL})$ then washed with aqueous saturated $\mathrm{NaCHO} 3$ solution $(3 \times 15 \mathrm{~mL})$ and water $(15 \mathrm{~mL})$. The organic layer was evaporated to obtain oily residue, which was dissolved in 2-MeTHF $(5 \mathrm{~mL})$. Triethyl amine $(0.18 \mathrm{~g}, 1.8 \mathrm{mmol})$ and a solution di-tert-butyl dicarbonate $(0.39 \mathrm{~g}, 1.8 \mathrm{mmol})$ in 2-MeTHF $(5 \mathrm{~mL})$ were added to the solution of S2 in 2-MeTHF. The resulting solution was stirred for $1.5 \mathrm{~h}$ at the room temperature. The solvent was evaporated in vacuo and the crude product was purified by column chromatography using EtOAc/heptanes (0-30\%) as eluent. The product containing fractions were concentrated in vacuo and triturated with ethanol to obtain 7 as yellow solid $(0.51 \mathrm{~g}, 54 \%) .{ }^{1} \mathrm{H}$ NMR (700 MHz, Chloroform- $d$ ) $\delta 11.61(\mathrm{~d}, J=71.0 \mathrm{~Hz}, 1 \mathrm{H}), 11.08$ (d, $J=101.7 \mathrm{~Hz}, 1 \mathrm{H}), 10.81(\mathrm{~s}, 1 \mathrm{H}), 8.78(\mathrm{~d}, J=15.3 \mathrm{~Hz}$, $2 \mathrm{H}), 8.06-7.67(\mathrm{~m}, 2 \mathrm{H}), 7.23-7.15(\mathrm{~m}, 2 \mathrm{H}), 7.00-6.92(\mathrm{~m}, 2 \mathrm{H}), 5.84(\mathrm{~d}, J=12.8 \mathrm{~Hz}, 2 \mathrm{H}), 5.41(\mathrm{t}, J=8.8 \mathrm{~Hz}$, 2H), $4.54(\mathrm{~d}, J=77.7 \mathrm{~Hz}, 2 \mathrm{H}), 3.91-3.37(\mathrm{~m}, 4 \mathrm{H}), 3.32-2.98(\mathrm{~m}, 4 \mathrm{H}), 2.61-2.38(\mathrm{~m}, 4 \mathrm{H}), 2.29-2.15(\mathrm{~m}, 5 \mathrm{H})$, $2.07-1.82(\mathrm{~m}, 14 \mathrm{H}), 1.78(\mathrm{~d}, J=12.2 \mathrm{~Hz}, 5 \mathrm{H}), 1.59(\mathrm{~s}, 2 \mathrm{H}), 1.44(\mathrm{~d}, J=50.8 \mathrm{~Hz}, 18 \mathrm{H}) .{ }^{13} \mathrm{C} \mathrm{NMR}(176 \mathrm{MHz}$, $\left.\mathrm{CDCl}_{3}\right) \delta 175.26,164.73,163.27,161.99,161.92,160.92,160.60,159.53,155.11,142.27,140.79,135.91,135.05$, 
$132.69,129.35,128.23,128.19,125.47,125.26,115.10,114.98,109.56,107.69,97.82,97.67,96.14,81.23,81.11$, $77.21,77.02,76.84,56.67,52.69,47.39,47.07,41.63,34.30,31.03,30.20,29.03,28.36,28.34,24.07$.

Synthesis of ClArArNHPro. To a suitable reaction vessel was charged pyrrolidine 1 (20.0 g, $28.3 \mathrm{mmol}$ ), $\mathrm{Pd}(\mathrm{OAc})_{2}(0.13 \mathrm{~g}, 0.60 \mathrm{mmol})$, Xantphos $(0.65 \mathrm{~g}, 1.1 \mathrm{mmol}), \mathrm{K}_{2} \mathrm{CO}_{3}(11.7 \mathrm{~g}, 85.0 \mathrm{mmol})$, Boc-ProNH ${ }_{2}(9.09 \mathrm{~g}, 42.4$ $\mathrm{mmol})$, and isopropyl acetate $(100 \mathrm{~mL}, 0.28 \mathrm{M})$. The solution was sparged with nitrogen for $15 \mathrm{~min}$ and subsequently heated to $85^{\circ} \mathrm{C}$ for $5 \mathrm{~h}$. The reaction mixture was cooled to the ambient, and the organic layer was washed with a solution of $5 \% \mathrm{~L}$-cysteine $/ 2.5 \% \mathrm{Na}_{2} \mathrm{CO}_{3}(140 \mathrm{~mL})$ and a solution of $5 \% \mathrm{Na}_{2} \mathrm{CO}_{3}(140 \mathrm{~mL})$. The resulting organic solution was filtered through a pad of Celite ${ }^{\circledR}$, rinsed with isopropyl acetate, and concentrated to an oil. The crude material was purified via silica gel chromatography (16 g Si/g 1, EtOAc:Hept gradient), and the product containing fractions were pooled and concentrated, yielding ClArArNHPro as a light-orange powder (9.96 g, 39.8\%). ${ }^{1} \mathrm{H}$ NMR $\left(700 \mathrm{MHz}, \mathrm{CDCl}_{3}\right.$ ) $\delta 11.19 \& 11.03$ (rotameric, $1 \mathrm{H}$ ), 8.77 (br s, 1H), 7.83 (br s, 1H), 7.57 (d, $J$ $=6.9 \mathrm{~Hz}, 1 \mathrm{H}), 7.38(\mathrm{~d}, J=8.9 \mathrm{~Hz}, 1 \mathrm{H}), 7.19(\mathrm{dd}, J=8.9,5.5 \mathrm{~Hz}, 2 \mathrm{H}), 6.95(\mathrm{t}, J=8.7 \mathrm{~Hz}, 2 \mathrm{H}), 5.84(\mathrm{~d}, J=12.2 \mathrm{~Hz}$, $2 \mathrm{H}), 5.42(\mathrm{~d}, J=6.6 \mathrm{~Hz}, 2 \mathrm{H}), 4.49 \& 4.38$ (rotameric, $1 \mathrm{H}), 3.62 \& 3.51$ (rotameric, $2 \mathrm{H}), 3.17-3.05(\mathrm{~m}, 4 \mathrm{H}), 2.61$ $2.48(\mathrm{~m}, 3 \mathrm{H}), 2.39-2.09(\mathrm{~m}, 2 \mathrm{H}), 2.04-1.97(\mathrm{~m}, 4 \mathrm{H}), 1.85-1.75(\mathrm{~m}, 4 \mathrm{H}) \quad 1.59-1.30(\mathrm{~m}, 9 \mathrm{H}) .{ }^{13} \mathrm{C}$ NMR $(176 \mathrm{MHz}$, $\left.\mathrm{CDCl}_{3}\right) \delta 172.87,172.47,164.67,163.20,161.99,161.96,161.11,161.06,160.61,160.49,159.71,159.65,155.41$, $154.20,144.25,144.24,142.36,142.34,140.00,139.93,139.85,136.17,132.66,130.14,130.05,128.25,128.21$, 125.37, 125.19, 125.15, 124.68, 120.03, 119.88, 119.85, 119.76, 119.68, 115.11, 114.99, 109.61, 109.45, 97.96, 97.80, 81.07, 62.74, 62.25, 56.75, 56.61, 52.51, 47.42, 47.10, 41.70, 34.47, 34.44, 30.94, 30.18, 28.37, 24.59, 23.94. 


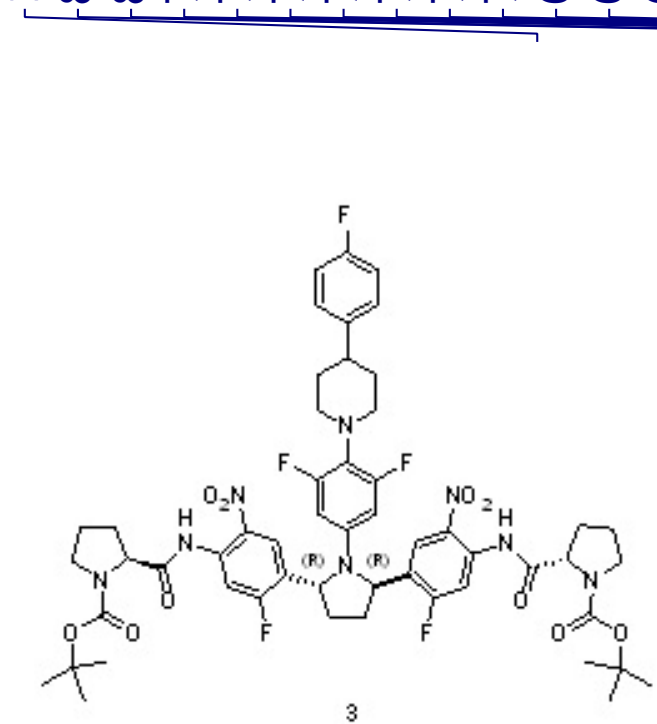

I JuUuU 700000 650000 600000 550000 $-500000$ 450000 400000 $-350000$ 300000 250000 $-200000$ 150000 100000 $-50000$

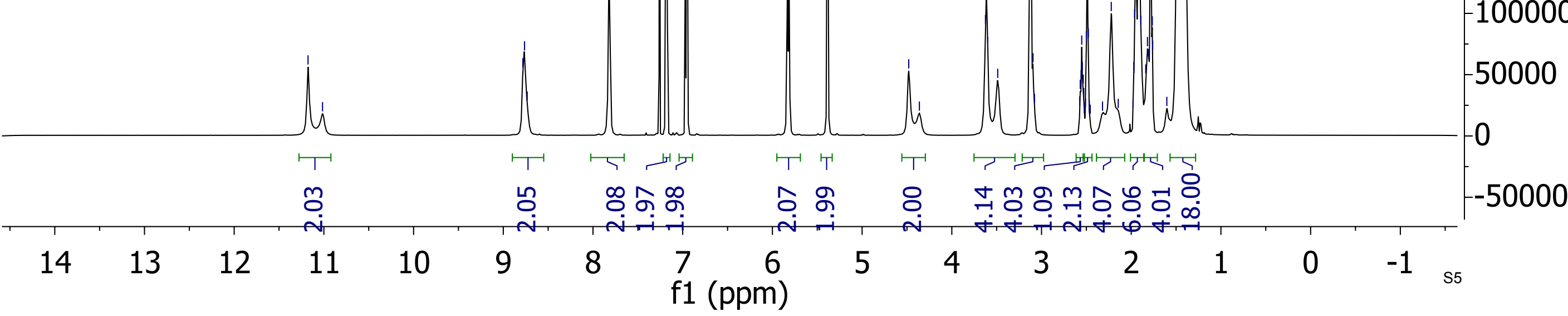




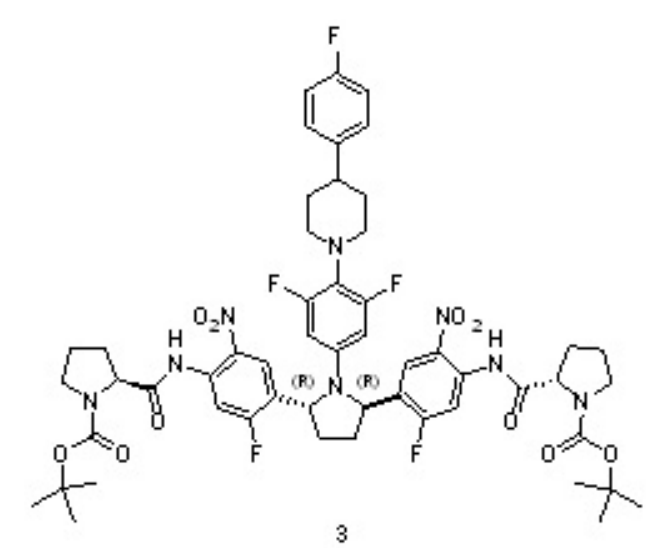

กn

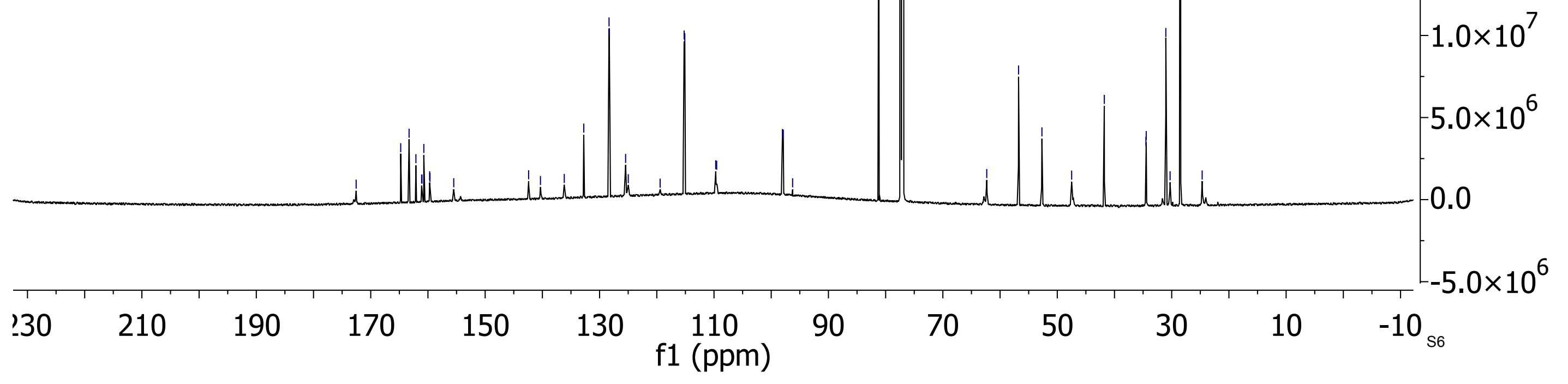




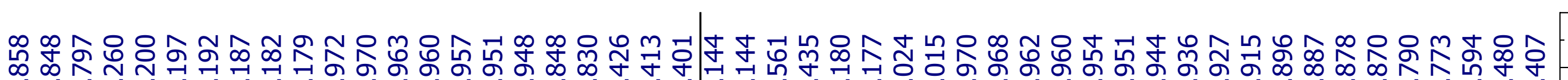

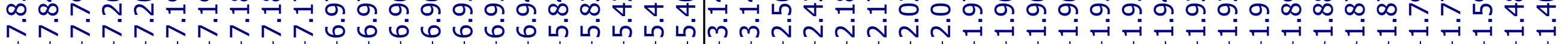

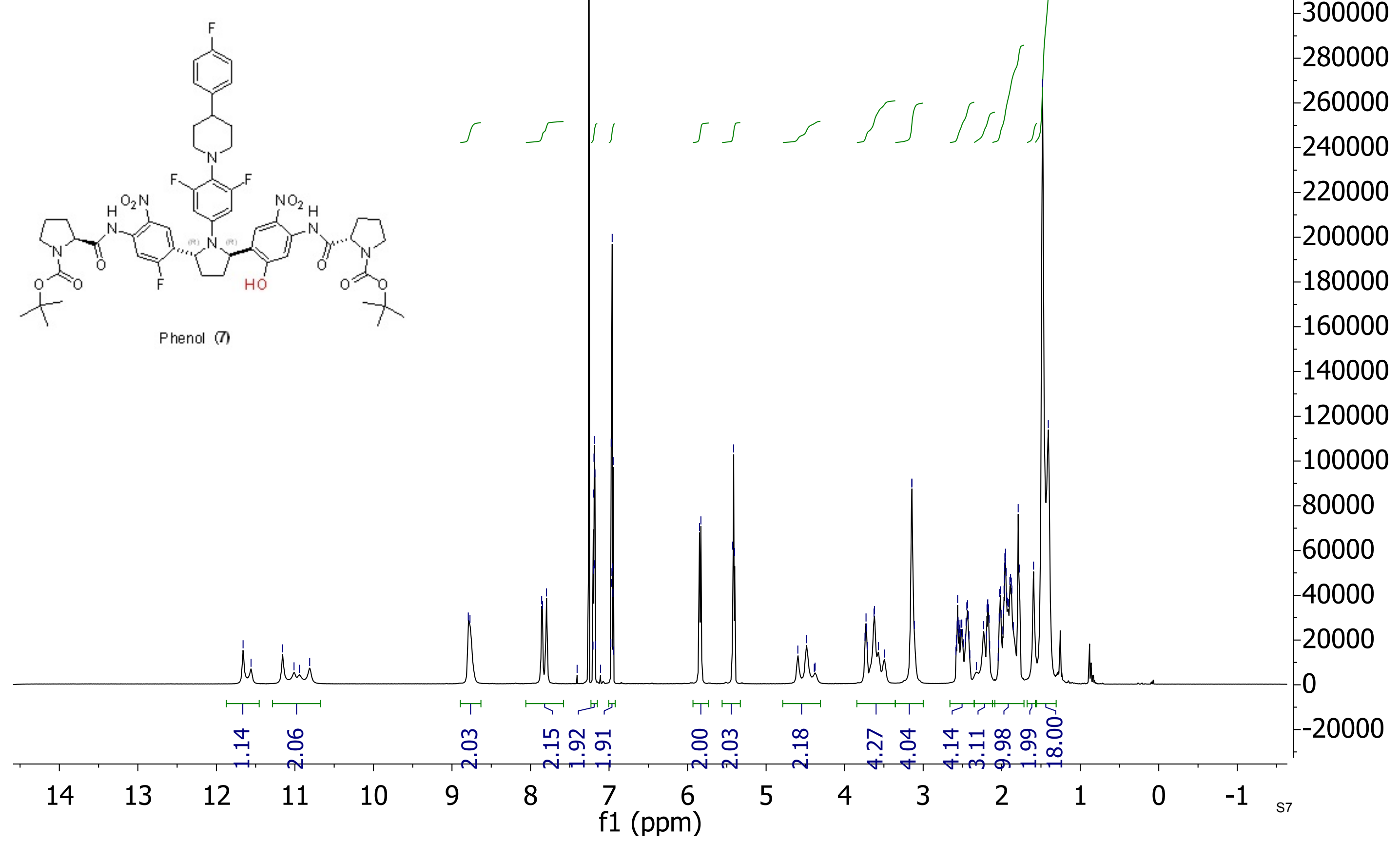



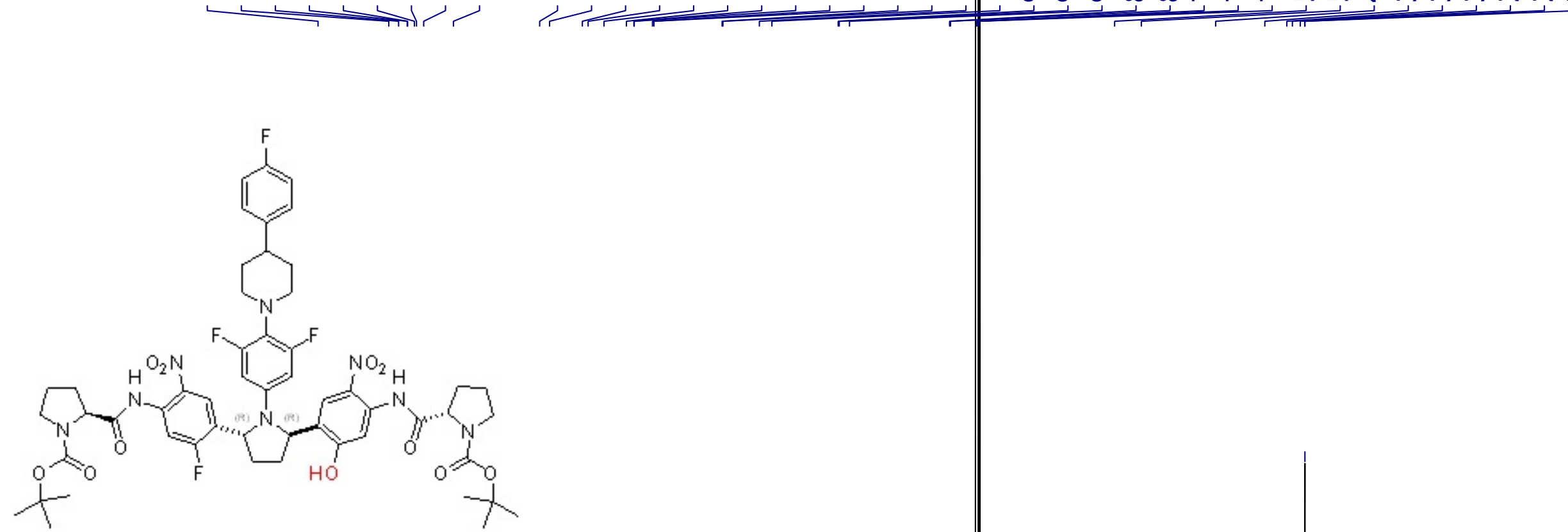

$-2.2 \times 10^{7}$

Phenol (7)

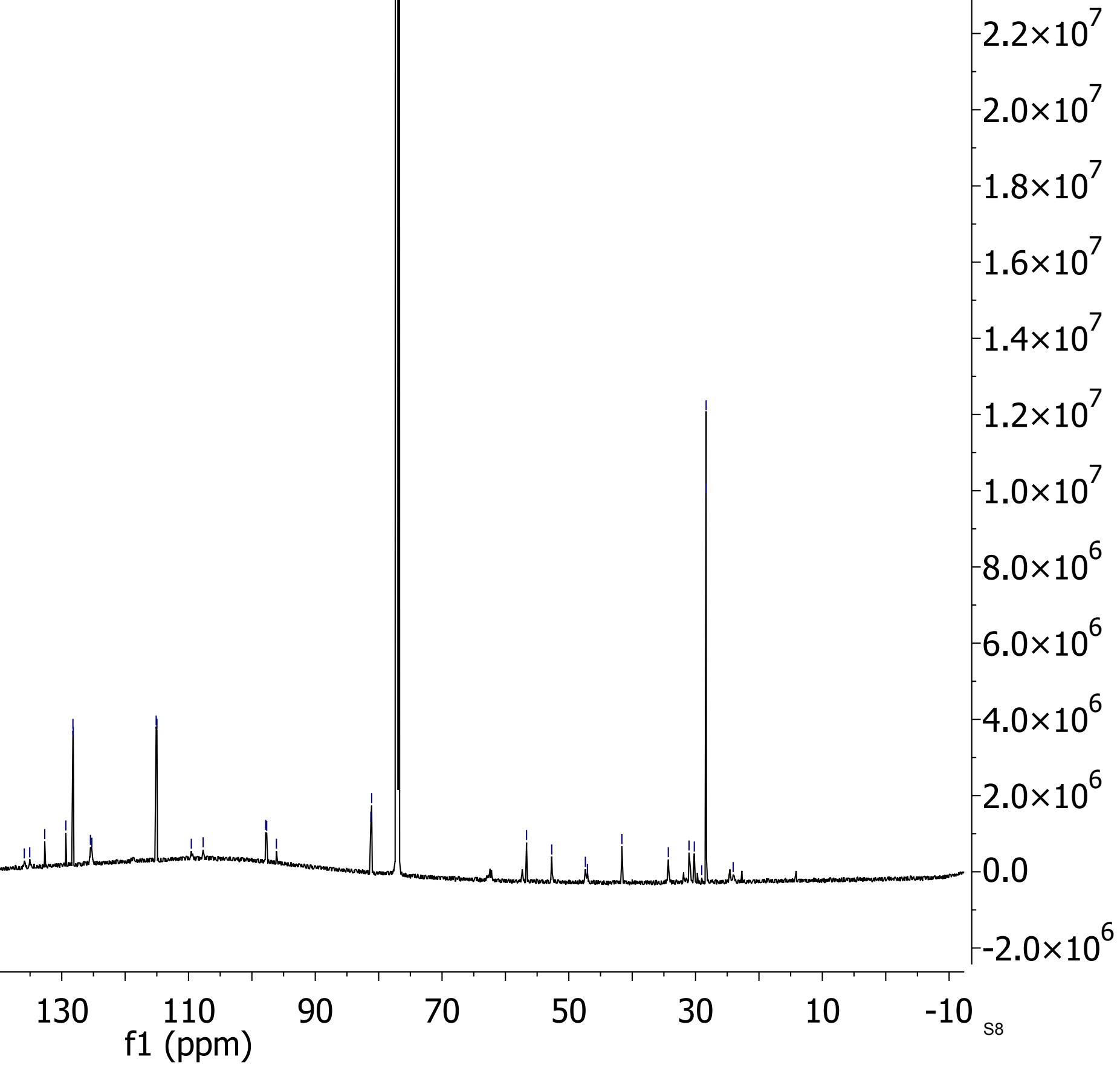




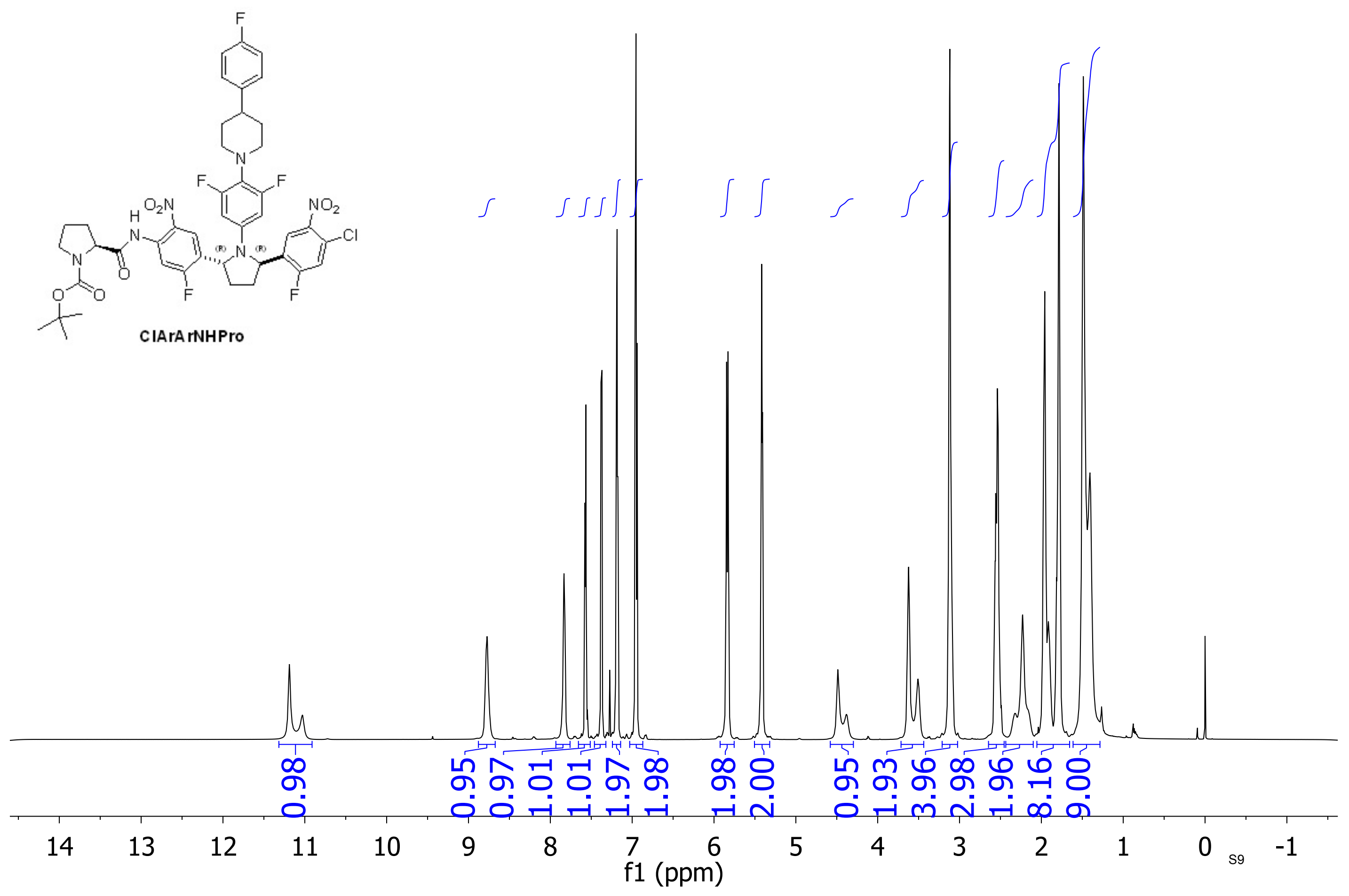




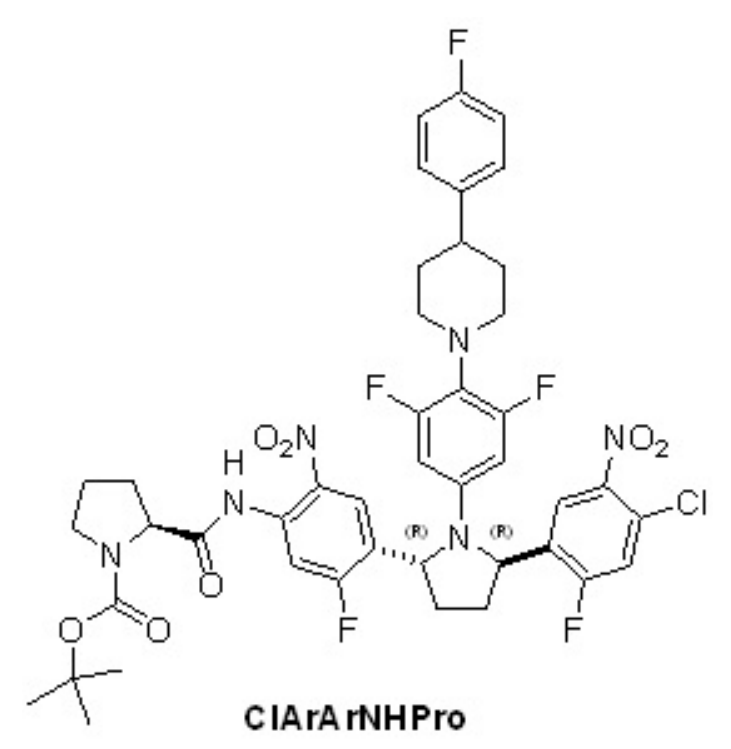

